\title{
Przemysław Stasiewicz
}

(Poznań)

\section{RETORYCZNY ASPEKT POLEMIKI RELIGIJNEJ Z PERSPEKTYWY LISTU STANISŁAWA HOZJUSZA DO MARCINA KROMERA Z 15 KWIETNIA 1551 R.}

\footnotetext{
Abstract

The aim of this paper is to show how a 16th-century Catholic clergyman would polemicize in the matter of religion with a Lutheran, whom he tried to convince to abandon erroneous (in his opinion) teachings. The author attempts to demonstrate the means and devices which Hozjusz employed for that purpose, and show the image of a heretic and a defender of faith conveyed in the letter to Marcin Kromer dated 15 of April 1551.

\section{Key words}

religious polemic, rhetoric, Reformation, Renaissance, Stanisław Hozjusz, Marcin Kromer, epistolography
} 


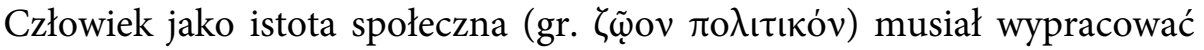
szereg praktyk, które pozwalały mu tworzyć relacje społeczne oraz zapewnić ich trwałość. Jedną z nich była sztuka rozwiązywania kwestii spornych za pomocą mniej lub bardziej przekonujących argumentów. W kulturze europejskiej do jej rozwoju przyczynili się niewątpliwie mieszkańcy antycznych greckich poleis, których życie na agorze skłaniało do tego rodzaju praktyk, rozwiniętych za sprawą sofistów ${ }^{1}$. Nie były one przy tym postrzegane jedynie jako konieczność. Świadczyć o tym mogą liczne agony ${ }^{2}$, pojawiające się w ówczesnych sztukach teatralnych. Istotą tej aktywności było przekonywanie odbiorcy do swych racji za pomocą siły wymowy oraz stosownego doboru słów, na co zwracał uwagę Kwintylian (35-96) przy ukazywaniu cech retory$\mathrm{ki}^{3}$. Z tego dziedzictwa antyku czerpały kolejne pokolenia polemistów. W ich obrębie ważną grupę stanowili apologeci chrześcijańscy, którzy bronili Tradycji apostolskiej przed zarzutami pogan i niewiernych. O jej niezwykle emocjonalnym zabarwieniu oraz jednocześnie autorytatywności przekazywanej kerygmy ${ }^{4}$ świadczy chociażby fragment z Listu do Galatów przypisywany św. Pawłowi z Tarsu:

Miror quod sic tam cito transferimini ab eo qui vos vocavit in gratiam Christi in aliud Evangelium: quod non est aliud, nisi sunt aliqui qui vos conturbant, et volunt convertere Evangelium Christi. Sed licet nos aut angelus de cælo evangelizet vobis præterquam quod evangelizavimus vobis,

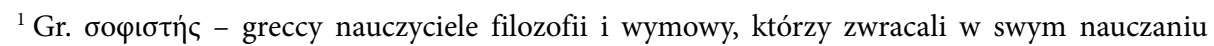
uwage głównie na to, by rozróżnienia na coś słusznego i niesłusznego, prawdziwego i fałszywego, doszukiwać się nie w obiektywnych normach, ale osobistym przekonaniu mówcy oraz celu mowy. Takiej metodzie sprzeciwiał się zdecydowanie Platon w dialogach „Fajdros” oraz „Gorgiasz”. Ich działalność przyczyniła się do rozwoju logiki i metod dowodzenia. Byli zarazem nauczycielami kosmologii, mitologii, historii kultury, ze szczególnym uwzględnieniem aspektów życia państwowego. Sofiści rozpoczęli swoją działalność w połowie V w. przed Chr. w Atenach za czasów Peryklesa. Wyróżnia się sofistów starszych (Protagoras, Gorgiasz, Hippiasz, Prodikos) i młodszych (Polus, Trasymach, Kalikles, Eutydemos, Dionosydoros, Antyfon). Cf. M. Brożek, Wstęp, [w:] M.F. Kwintylian, Kształcenie mówcy: księgi I, II i X, przeł. M. Brożek, Wrocław 1951, s. IX-XI; Wielka Ilustrowana Encyklopedia Powszechna Wydawnictwa Gutenberga, 16, Kraków 1995, s. 121.

${ }^{2} \mathrm{Gr} . \dot{\alpha} \gamma \omega \dot{\omega} v$ - turnieje oratorskie organizowane przez Ateńczyków ku czci bogini Perwazji

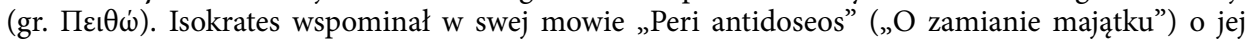
kulcie oraz tym, że była w orszaku Afrodyty lub Ateny. Celem tych turniejów nie było odkrywanie prawdy, ale pokonanie lub przekonanie do swych racji przeciwnika. Cf. M. Korolko, Przewodnik encyklopedyczny, Warszawa 1990, s. 31-32.

${ }^{3}$ Dla Kwintyliana była również sztuką właściwego posługiwania się słowem (bene dicendi scientia Quint. Inst. II 14,5), J.Z. Lichański, Retoryka od średniowiecza do baroku, Warszawa 1992, s. $19-20$.

${ }^{4}$ Gr. $\kappa \eta ́ p v \gamma \mu \alpha$ - prawowierne nauczanie, przepowiadanie; por. [online]. Bible Hub [dostęp: 2015-12-27]. Dostępny w Internecie: <http://biblehub.com/greek/2782.htm>.
} 
anathema! Sicut prædiximus, et nunc iterum dico: si quis vobis evangelizaverit præter id quod accepistis, anathema sit! 5

W podobnym duchu prawd wiary broniły następne pokolenia polemistów chrześcijańskich, do których można zaliczyć również żyjącego w czasach reformacji Stanisława Hozjusza ${ }^{6}$. Jego niechęć wobec odstępców, a szczególnie głoszonych przez nich poglądów niezgodnych z nauczaniem Magisterium Kościoła katolickiego, była dostrzegalna już w młodzieńczej twórczości. Jej przykłady możemy odnaleźć chociażby w jego epigramie skierowanym przeciwko zwolennikom nauk Marcina Lutra (1483-1546): „Stanislai Hosii Cracoviani in Lutheri sectatores epigramma" z 1526 r. ${ }^{7}$ Ten utwór cechuje ironia względem innowierców, dostrzegalna również w późniejszej twórczości polemisty ${ }^{8}$, w dziełach takich jak choćby „Księgi o Jasnym a Szczyrym Słowie Bożym Najjaśniejszemu Książęciu i Panu Zygmuntowi Augustowi, etc. Przypisane", „Rozmowa o tym: Godzi li się laikom kielicha, księżej żon dopuścić, a w kościelech służbę Bożą językiem przyrodzonym sprawować”10, „Odparcie

\footnotetext{
${ }^{5}$ „Nadziwić się nie mogę, że od Tego, który was łaską Chrystusa powołał, tak szybko chcecie przejść do innej Ewangelii. Innej jednak Ewangelii nie ma: są tylko jacyś ludzie, którzy sieją wśród was zamęt i którzy chcieliby przekręcić Ewangelię Chrystusową. Ale gdybyśmy nawet my lub anioł z nieba głosił wam Ewangelię różną od tej, którą wam głosiliśmy - niech będzie przeklęty! Już to przedtem powiedzieliśmy, a teraz jeszcze mówię: Gdyby wam kto głosił Ewangelię różną od tej, którą [od nas] otrzymaliście - niech będzie przeklęty!" Gal 1, 6-9.

${ }^{6}$ Stanisław Hozjusz (1504-1579) - urodzony w Krakowie w spolonizowanej badeńskiej rodzinie mieszczańskiej. Uzyskał w 1520 r. bakalaureat sztuk wyzwolonych, a w 1534 tytuł doktora obojga praw na Uniwersytecie w Bolonii. Pracował w kancelariach biskupów krakowskich, a od $1538 \mathrm{r}$. jako sekretarz w kancelarii królewskiej. Biskup chełmiński (nominacja w 1549 r., przyjęcie Sakry w 1550 r.) i biskup warmiński (od 1551 r.), a od 1561 - kardynał. Na konklawe w 1565 r. był jednym z papabili. W $1564 \mathrm{r}$. wprowadził jezuitów do Braniewa, a od roku 1569 przebywał już na stałe w Rzymie. Był członkiem kilku dykasterii rzymskich. W 1574 r. zaszczytny urząd Wielkiego Penitencjarza. Zmarł w Capranice pod Rzymem 5 sierpnia 1579 r. Cf. W. Urban, Stanisław Hozjusz, PSB 1962-1964, 10, s. 42-46.

${ }^{7}$ Stanislai Hosii Cracoviani in Lutheri sectatores epigramma, [w:] Erasmus Roterodamus, Hyperaspistes diatribae adversus Servuum Arbitrium Martini Lutheri, Cracoviae 1526.

${ }^{8}$ Heinrich Lausberg zwracał uwagę, że ironia jest ułomnością, wadą (łac. vitium) wobec prawdomówności z punktu widzenia etyki. Jednak z perspektywy erazmiańczyka, jakim był Stanisław Hozjusz, nadawała się doskonale do napiętnowania i wyszydzenia pewnych aspektów postępowania reformowanych oraz ich poglądów. Podobnie czynił to chociażby Erazm z Rotterdamu (1467-1536) w odniesieniu do pewnych katolickich praktyk, jak pielgrzymki czy kult relikwii, w „Pochwale głupoty”. Cf. H. Lausberg, Retoryka literacka. Podstawy wiedzy o literaturze, przeł. i oprac. A. Gorzkowski, Bydgoszcz 2002, s. 902.

${ }^{9}$ S. Hosius, De Expresso Dei verbo: Ad Serenissimvm Dominvm, Dominvm Sigismvndvm Avgvstvm, Dei Gratia Regem Poloniae... Libellvs Valde Vtilis [...], Dilinga 1558.

${ }^{10}$ Idem, Dialogus De Eo Num Calicem Laicis et uxores Sacerdotibus permitti ac divina officia vulgari lingua peragi fas sit[...], [w:] Opera omnia in duos divisa tomos [...], 1-2, Coloniae 1584.
} 
przedłożeń Brencjusza”11 czy „Chrześcijańskie wyznanie wiary katolickiej”"2, ale także w spuściznie epistolograficznej, której uczeni poświęcają mniej uwagi niż wspomnianym utworom. Do tej pory opublikowano zaledwie trzecią część korespondencji hozjańskiej. Z niej jedynie ułamek znalazł się w zbiorze „Opera Omnia” wydanym w Kolonii w 1584 r. przez Stanisława Reszkę ${ }^{13}$. W tej edycji znalazł się łaciński list ${ }^{14}$, któremu zamierzam się bliżej przyjrzeć $\mathrm{w}$ niniejszym artykule. Był on skierowany przez ówczesnego biskupa chełmińskiego, nominata na biskupstwo warmińskie, Stanisława Hozjusza, do Marcina Kromera ${ }^{15}$. Przetłumaczony na język polski został dopiero po kilku stuleciach przez Juliana Wojtkowskiego ${ }^{16}$. Znalazł się w tomie „O postępowaniu $\mathrm{z}$ odłączonymi”. List ukazuje stosunek Stanisława Hozjusza do innowiercy Urbana Stömera, będącego rektorem szkoły w Toruniu ${ }^{17}$. Postaciom przywołanym w tym liście przypisano pewne wyraziste przymioty, które dla każdego czytelnika były przejrzyste ${ }^{18}$. Zamierzam się przyjrzeć obrazowi tych postaci oraz środkom perswazji, jakie stosował Stanisław Hozjusz w celu nawrócenia niewiernego. Jednak wpierw należy poświęcić nieco miejsca kontaktom listownym między Stanisławem Hozjuszem a Marcinem Kromerem.

Korespondencja między nimi do roku 1551 nie była zbyt częsta - narastać zaczęła dopiero wraz z upływem czasu, kiedy Stanisław Hozjusz (ryc. 1) obejmował coraz ważniejsze stanowiska na dworze monarszym (został następcą na stanowisku sekretarza króla Zygmunta I Starego po śmierci Jana

\footnotetext{
${ }^{11}$ Idem, Confutatio prolegomenon Brentii, quae primum scripsit adversus venerabilem virum Petrum à Soto [...], Antwerp 1561.

${ }^{12}$ Confessio fidei catholicae Christiana, avthoritate Synodi prouincialis quae habita est $\mathrm{Pe}$ trcouiae, anno M. D. LI. Mense Iunio, edita: Praesid[en]te Peuerendissimo in Christo patre Domino dno Nicolao, Dei gratia Archiepiscopo Gnesnensi legato, nato et regni primate, Cracoviae 1553.

${ }^{13} \mathrm{~S}$. Hosius, Opera omnia in duos divisa tomos [...], 1-2, Coloniae 1584.

${ }^{14} \mathrm{~W}$ kontaktach listownych Stanisław Hozjusz używał głównie łaciny oraz języka niemieckiego. Jednak listy do Hozjusza bywały pisane również w języku polskim. Czynił tak niewątpliwie Jan Kostka (1529-1581), sekretarz królewski (od 1554 r.); cf. W. Szczuczko, Łacina szlachty Prus Królewskich w XVI i XVII wieku, [w:] J. Axer (red.), Łacina jako język elit, Warszawa 2004, s. 127.

${ }^{15}$ Marcin Kromer (1512-1589) h. własnego, biskup warmiński, dyplomata, historyk, pisarz kontrreformacyjny. Cf. H. Barycz, Kromer Marcin, PSB 1970, 15, s. 319-325.

${ }^{16}$ S. Hozjusz, O postępowaniu z odłączonymi, przeł. J Wojtkowski, Olsztyn 2009.

${ }^{17}$ J. Wojtkowski, Czynności religijne Stanisława Hozjusza w diecezjach: chełmińskiej i warmińskiej, [w:] S. Achremczyk, J. Guzowski, J. Jezierski (red.), Kardynał Stanisław Hozjusz (1504-1579). Osoba, myśl, dzieło, czasy, znaczenie, Olsztyn 2005, s. 78.

${ }^{18}$ Stanisław Hozjusz pamięta o jasności, wyrazistości swego wywodu (łac. perpsicuitas ceniona przez Kwintyliana), dostosowaniu treści do odbiorcy (łac. aptum) oraz jego ozdobności (łac. ornatus), m.in. dzięki cytatom, co świadczyło o jego znajomości zasad retoryki; cf. Quint. Inst. VIII 2, 22, Cic. De Or. II 12, 49.
} 
Gamrata), a następnie duchowne ${ }^{19}$. Podobną uwagę można odnieść do osoby Marcina Kromera (ryc. 2). W 1533 r. uzyskał on bakalaureat na Akademii Krakowskiej, a następnie pobierał nauki w Italii i tam otrzymał również tytuł Doktora Obojga Praw (łac. Iuris Utriusque Doctor). Poznał tam, podobnie jak wspomniany syn Ulryka, Lazzara Bonamica (1479-1552), u którego pobierał lekcje łaciny oraz greki.

Te dwie postaci łączyła również chęć upowszechniania greckiego dorobku piśmienniczego Jana Chryzostoma czytelnikom nieznającym tego języka ${ }^{20}$. Dokonali tego przez translację jego dzieł na język łaciński. Kromer opublikował jedno z jego dzieł, na które natknął się podczas pobytu w Bolonii ${ }^{21}$. Były to „Eklogi”. Zostały przez niego wydane w oficynie bazylejskiej w roku 1552 , co przyniosło mu rozgłos i ogólnoeuropejską sławę $e^{22}$. Pomogło mu to $\mathrm{w}$ pozyskiwaniu możnych protektorów, którym dedykował swoje pisma. W tym gronie znalazły się osoby dobrze znane przyszłemu Wielkiemu Penitencjarzowi, jak biskup krakowski Piotr Tomicki (1464-1535) oraz książę pruski Albrecht Hohenzollern (1490-1568). Z tego względu nawiązanie bliższych kontaktów między Kromerem i Hozjuszem było tylko kwestią czasu. Na podstawie zachowanego materiału epistolarnego można stwierdzić, że utrzymywali znajomość najpóźniej od roku $1537^{23}$. Hozjusz informował w nim o sprawach bieżących, a jednym z poruszonych problemów była kwestia zostania Miastkowskiego kanonikiem sądeckim ${ }^{24}$. Jednak ich kontakty zaczęły się zacieśniać później, gdy obydwoje przyjęli prawie jednocześnie święcenia kapłańskie (Kromer w roku 1542, a Hozjusz w 1543). Ostatecznie pełnili ważne funkcje w diecezji warmińskiej, gdzie Kromer był kanonikiem (1551), a Stanisław Hozjusz biskupem (1551). Z 15 kwietnia tego roku pochodził list, w którym Hozjusz informował swojego drogiego przyjaciela o działaniach „Nauczyciela” (Ludimagister), Urbana Stömera. Działał on w Toruniu, którego parafie podlegały władzy zwierzchniej biskupa chełmińskiego. Był nim jeszcze wówczas Stanisław Hozjusz, choć otrzymał już nominację na stanowisko biskupa warmińskiego.

\footnotetext{
${ }^{19}$ Cf. notka biograficzna w przyp. 6.

${ }^{20}$ Stanisław Hozjusz przetłumaczył w 1528 r. utwór Jana Chryzostoma, który ukazał się pod tytułem „Libellus elegans, in quo confert verum monachum cum princibus, divitibus ac nobilibus huius mundi”. Cf. PG, XLVII, kol. 387-392; F. Hipler, Johannes Chrisostomus und Stanislaus Hosius, PDE 2, 1878, s. 21-23; HV, I, s. 23.

${ }^{21}$ H. Barycz, Kromer Marcin, s. 321.

${ }^{22}$ Ibidem.

${ }^{23} \mathrm{~W}$ edycji Hiplera i Zakrzewskiego najwcześniejszy list między nimi pochodzi z 9 grudnia 1537 r. Cf. St. Hosius Martino Kromero, Cracoviae 9 Decembris 1537, HE, s. 51-52.

${ }^{24}$ Ibidem, s. 52.
} 
Ten materiał epistolograficzny znalazł się ostatecznie $\mathrm{w}$ tomie drugim zbioru „Opera omnia” Stanisława Hozjusza ${ }^{25}$. List charakteryzuje bogactwo retoryczne, którym nie może poszczycić się żaden z listów adresowanych do Kromera w edycji Hiplera i Zakrzewskiego. Na samym początku jego autor opisał w nim sytuację, która wzbudziła jego niepokój po przybyciu do Torunia. $\mathrm{Z}$ pewnością mogły pojawić się wówczas pierwsze podejrzenia co do przenikania wpływów reformatorów w obrębie jego diecezji. Sytuację tę ukazał Kromerowi dosyć szczegółowo w następujących słowach:

Habitae sunt supplicationes in ipso ingressu meo in templum: audivi Patrem eos, Filium, Spiritum sanctum, et sanctam Trynitatem, pro misericordia deprecan: mox omissa sanctorum intercessionem illus occinentes. Propitius esto, parce nobis Domine et reliqua deinceps. Audivi postea sacrum cantari, quo absoluto quaesivi ex Parocho $^{26}$.

Pominięcie ustępu o Wszystkich Świętych było dla tego dostojnika kościelnego bardzo rażące. Podejrzewał, że działania te musiały być związane $\mathrm{z}$ działalnością jakiegoś człowieka w duchu reformacyjnym. Wkrótce zjawił się u niego prawdopodobny prowodyr Urban Stömer i stwierdził, że nie był odpowiedzialny za to zajście, a postępował zgodnie z tym, co zostało mu przekazane: „Ludimagister (...) dixit (...) nonnulius mutationis author fuerit: sed quod sibi per manus fuit traditum, id retinuerit"27. Jednak nie oznaczało to, że nie był on odpowiedzialny za wprowadzanie zmian, o czym upewnił biskupa chełmińskiego być może nieopatrznym spostrzeżeniem:

Se paratum esse doceri, certa ipse, quod nihil cum imperio et auctoritate essem acturus, sed ita ut scripto meo me facturum recepissem in Spiritu lentitatis, cum praesertim a multis lenitatem et mansuetudinem meam praedicari audivisset, simul et illus iudicavit, sibi si persuadissem, fore, ut multi eandem doctrinam amplecterentur ${ }^{28}$.

W tym fragmencie pojawiło się również nawiązanie do wcześniejszego zapewnienia ze strony Stanisława Hozjusza, który wspominał, że nie będzie surowy wobec osób mających wątpliwości związane z Sakramentem Eucharystii („de Sacramento Eucharistio dubitaret”) ${ }^{29}$. Zgodność postępowania Hozjusza $\mathrm{z}$ prezentowanymi przez siebie wytycznymi została w tekście listu do Kromera przeciwstawiona skrytości zamiarów zwolennika reformacji, który

\footnotetext{
${ }^{25}$ S. Hosius, Opera omnia, s. 61-70.

${ }^{26}$ Ibidem, s. 61 .

${ }^{27}$ Ibidem.

${ }^{28}$ Ibidem, s. 62.

${ }^{29}$ Ibidem.
} 
mimo spotkań ze wspomnianym hierarchą i zapewnień o braku złych intencji realizował podstępnie swój plan. Świadczyły o tym kolejne wprowadzane przez niego modyfikacje, jak opuszczenie podczas śpiewów pieśni Maryjnej „Salve Regina” na rzecz „Salve Rex misericordia” oraz brak szacunku wobec Najświętszego Sakramentu wśród wiernych, co przedstawił w tych słowach: „pueri vero omnes terga verterunt versus illam, neque ullum Christi corpori honorem habebant"30. Biskup mimo swojego oburzenia nie uczynił nic niezgodnego z łagodnością (łac. clementia) i tylko wezwał Urbana Stömera na kolejną rozmowę.

Sprawa ta w dużej mierze sprowadzała się do kwestii autorytetu, o której wspominał w tych słowach:

Dixi illi Ludimagistro, mihi minime probari quod sibi tantum sumeret, ut sibi iudicium arrogaret inter Ecclesiam Catholicam et Martinum, qui $\mathrm{ab}$ ea discessisset, atque illius doctrinam Ecclesiae doctrinae anteponeret, eamque universam erroris condemnaret. Non esse unius hominis hac de re que esse unius hominis iudicium privati praesertim: neque esse unius hominis convellere velle, quae sunt a Christi corpore, a Sancta Catholica Apostolica Ecclesia, de unanimi consensu omnium constituata ${ }^{31}$.

Widać kolejne porównanie i zestawienie z jednej strony Hozjusza, jako przedstawiciela autorytetu zbiorowego w postaci Kościoła Powszechnego istniejącego od antycznych ${ }^{32}$ czasów apostolskich (,a Christi corpore, a Sancta Catholica Apostolica Ecclesia"), a z drugiej - Urbana Stömera, który działał na własną rękę i wykazywał się w jego oczach z pewnością dużą pychą - tym bardziej, że był prostym człowiekiem („privati praesertim”) w jego mniemaniu i nie zmieniało tego również to, że przebywał w zagranicznych ośrodkach reformacyjnych, a nawet zasiadał przy stole Marcina Lutra („D. Martinum ad latus illius in tabula saepe sedisse”) ${ }^{33}$. Ten prywatny autorytet był również powiązany z innym aspektem protestanckiej nauki, która wiązała się z osobistą interpretacją Pisma Świętego.

O tym wspominał Hozjusz w pierwszej części listu, gdy nakazał rozwiesić w czwartą Niedzielę Wielkiego Postu („Laetare”) na drzwiach tamtejszych

${ }^{30}$ Ibidem.

${ }^{31}$ Ibidem, s. 62-63.

${ }^{32}$ Słowa „antyczny” używam tak jak Jaques Le Goff, który w XVI-wiecznej Francji spostrzegł prawidłowość, że najbardziej ceniono to, co uchodziło za antyczne (miało przynajmniej 1000-letnią tradycję), mniej - dawne (liczące najmniej 200 lat) i najmniej - stare, mające minimum 100 lat. Użycie tego argumentu w polemice można uznać za jak najbardziej celowe ze strony Hozjusza. Cf. J. Le Goff, Historia i pamięć, przeł. A. Gronowska, J. Stryjczyk, Warszawa 2007, s. 70.

${ }^{33}$ S. Hosius, Opera omnia, s. 62. 
świątyń następujące wezwanie: „admonebam, ut omnes idipsum saperent, neve vellent omnes Apostoli esse aut Pastores (...)"34. Wskazał w swojej argumentacji na to, że głoszone przez nich Słowo Boże nim nie było („Dei verbum vocare, quod Dei verbum non sit” ${ }^{35}$, ponieważ nadawali Jemu swój własny sens („suum ad scripturas sensum adferant”) ${ }^{36}$. Tak czynili również duchowi poprzednicy toruńskiego reformatora $\mathrm{w}$ okresie patrystycznym. Biskup chełmiński wspomniał o dość jaskrawym przykładzie, jakim był prezbiter aleksandryjski Ariusz (zm. 336), który: „produxisse scripturam, Pater maior me est ${ }^{37}$, tanquam Dei Verbum, cum tamen Deus nunquam id intellectum per hanc scripturam voluerit, quod intelligebat Arrius, Esse ulla in re filium quarentus Deus est, inferiorem Patrem"38. Posłużył się przykładem tej postaci, ponieważ była ona dobrze znana i stanowiła ilustrację tego, jak błędne wnioski można było wyciągać na podstawie wyjętego z kontekstu ustępu. Wśród antycznych mącicieli wymienił również syryjskiego mnicha Nestoriusza (384-451) oraz biskupa Kartaginy Donata (zm. 355). Powołał się także na przykład Galatów, którym przekazano błędne nauki pod pozorem Słowa Bożego ${ }^{39}$. Odwoływał się do tego motywu biblijnego dość chętnie. Pojawił się on również w "Postępowaniu z elblążanami” spisanym dwa lata później (1553): „Quin et Galatis, qui renunciabant, aliud, quam quod acceperant a Paulo, sub specioso Evangelii titulo doctrinam suam populo venditasse legimus" ${ }^{40}$.

Jednak wspomniane poglądy wśród odszczepieńców (łac. haereticos) nie były stałe i ulegały zmianom. Hozjusz użył ironicznego wyrażenia odnoszącego się do pewnego katolickiego księcia Jerzego. Zarówno w łacińskiej, jak i polskiej edycji listu nie pojawia się wzmianka o tym, kim mógłby on być. Osobiście postarałem się sprawdzić tzw. trop erazmiański, ponieważ Hozjusz cenił osoby, które były katolikami, utrzymywały przyjacielskie kontakty z Erazmem z Rotterdamu oraz wypowiadały się dość stanowczo przeciwko innowiercom lub ich postępowaniu. Było tak między innymi w przypadku biskupa Rochester, kardynała Johna Fishera (1469-1535), sprzeciwiającego się rozwodowi króla angielskiego Henryka VIII (1491-1547) z Katarzyną Aragońską (1485-1536) i jego powtórnemu małżeństwu z Anną Boleyn

\footnotetext{
${ }^{34}$ Ibidem, s. 61-62.

${ }^{35}$ Ibidem, s. 62.

${ }^{36}$ Ibidem.

${ }^{37}$ Ioann 14,28

${ }^{38}$ S. Hosius, Opera omnia, s. 61-70.

${ }^{39}$ Ibidem.

${ }^{40}$ Ibidem, s. 71.
} 
(zm. 1536), co przypłacił życiem. Został on wymieniony w liście gratulacyjnym Hozjusza do kardynała Reginalda Pole'a (1500-1558) z 7 kwietnia 1537 r. jako wzór cnót ${ }^{41}$. Jedynym księciem Jerzym, który spełniałby to kryterium, jest według mnie władca saski $\mathrm{z}$ dynastii Wettinów, który utrzymywał kontakty listowne z Erazmem z Rotterdamu: „(...) wissenschaftlich angeregt [Herzog Georg der Bärtige] durch seinen Briefwachsel mit Erasmus" ${ }^{42}$. Sformułowanie zaprezentowane przez biskupa chełmińskiego z pewnością pasowałoby do erazmiańczyka:

Princeps Catholicus Georgius, se scire quam hoc anno fidem haberent vicini sui Wittenbergenses, quam autem essent in sequenti anno habituri se nescire: quod subinde novarent, adderent, detraherent aliquid: Quoties locos suos communes, quoties Commentarios in Epistolam ad Romanoas mutavit Philippus? Pugnant postrema cum primis, neque in eorum doctrina stabile quicquam est et diuturnum ${ }^{43}$.

Ten fragment należałoby uznać za jeden $\mathrm{z}$ ciekawszych ze względu na użyte środki wyrazu. Pojawiły się w nim wyliczenia „ile razy”(quoties), które występowały w pytaniu retorycznym. Oprócz tego dokonano personifikacji założeń, twierdząc, że walczą one między sobą („pugnant postrema cum primis”). Ponadto opinia o tym, że król wie, jakie poglądy mieli Luteranie obecnie, ale nie wiedział, jakie będą one w następnym roku („essent in sequenti anno habituri se nescire"), ukazywać miała zmienność poglądów również samego Marcina Lutra. To właśnie przedstawił Hozjusz Urbanowi Stömerowi jako jeden z głównych zarzutów. Z listu wynika, że nie określił go jednak ani razu mianem największego heretyka (haereticissimus), jak uczynił to wobec byłego francuskiego kardynała (który dokonał konwersji na kalwinizm) Odeta de Coligny de Châtillona (1517-1571) w liście skierowanym do Marcina Kromera z 16 września 1561 r. $^{44}$

Zapewne to do osoby Wittenberskiego reformatora odnosiło się sformułowanie użyte przez Stanisława Hozjusza, które należałoby uznać za ironiczną aluzję do jego związku z Katarzyną von Bora (1499-1552). Mariaż ten autor potraktował jako nikczemny wzorzec postępowania przyszłych burzycieli ładu ustanowionego przez dekrety soborowe: „Expetere multos Concilium,

${ }^{41}$ „(...) Roffenses quoque Erasmos collegas habiturus nisi crudelis mors hunc illis honorem indivisset”. Cf. Stanislaus Hosius Polonus Reginaldo Polo Cardinali, Cracoviae, 7 Aprilis 1537, HE 11, s. 44.

${ }^{42}$ E. Werl, Georg der Bärtige (oder der Reiche), NDB 6, Berlin 1964, s. 226.

${ }^{43}$ S. Hosius, Opera omnia, s. 63.

${ }^{44}$ „De Cardinale Schatillion falsum erat quod tibi scripseram. Haereticissimus est”. Cf. Autograf BJ, rkps 60, s. 1025, pieczęć i adnotacja Kromera 26 Septembris Pragae. 
quis autem dixi futurus est usus Concilii, si simul Monachum aliquem Monachae libido coeperit, omnia illi reficiendere licebit quae sunt in Concilio decreta" ${ }^{35}$. Podobnego określenia w stosunku do reformatora użył w zestawieniu jego poglądów i stanowiska soborowego, zarzucając Urbanowi Stömerowi przedkładanie stanowiska Lutra nad decyzje Koncylium:

Ego tuum illum qui cestro libidinis erga Monialem percitus cum ipse Monachus esset, quo facilius posset libidini suae satisfacere turbavit orbem universum, et Ecclesiae doctrinam convellere conatus est: hunc ego sequar? Hunc anteponam Conciliis duobus: omnia mihi prius ut eripiat Deus, precor, quam ut mea mente ut ea mente me esse permitta ${ }^{46}$.

Widać, że ówczesny biskup chełmiński zarzekał się, że nigdy by tak nie postąpił, używając pytań przed udzieleniem odpowiedzi. W ten sposób starał się podkreślić, że inna odpowiedź będzie charakteryzowała tylko człowieka nierozumnego. Pojawiły się dwa autorytety $-\mathrm{z}$ jednej strony Kościoła i dwóch Soborów, a z drugiej - rozwiązłego wichrzyciela Marcina Lutra. W powyższych fragmentach widać również sprzeciw ze strony Hozjusza wobec łamania celibatu przez duchownych. Wypowiedział się on o tym szerzej w dziele już wspomnianym: „Rozmowa o tym: Godzi li się laikom kielicha, księżej żon dopuścić, a w kościelech służbę Bożą językiem przyrodzonym sprawować” (...). W podobnym ironicznym tonie było to przedstawione także w „Postępowaniu z elblążanami” (1553):

Quis mei inquam, apud vos usus fuerit, quandoquidem ipsi vos estis concilia, ipsi Papae, ipsi Epicopi, Pastores, Doctores, ipsi scripturas interpretamini arbitratu vestro, denique negatis plerique cure cuiquam esse debere salutem animalum vestrarum; praeterquam vobis ipsis. Quin et uxores vestre Episcope sunt et summi Pontificis sibi munus usurpant, in scripturis interpretandis: authoritatem sibi Episcoporum vendicant ${ }^{47}$.

W tym fragmencie widać wyraźnie, że przywódcy reformacji, którzy między sobą uchodzili za Papieży, Biskupów, Duszpasterzy oraz Doktorów („ipsi Papae, ipsi Epicopi, Pastores, Doctores"), nie byli jednak całkowicie niezależni. Podlegali wyższej władzy, którą posiadały nad nimi ich żony, porównane w tym tekście do Papieżyc, Biskupic itd.

Tekst wyraźnie akcentuje podziały i niezgodność w poglądach między protestantami, co odnajdujemy również we wcześniejszym liście do Kromera z 15 kwietnia 1551 r. Sposobnością do tego było zaprzeczenie ze strony

\footnotetext{
${ }^{45}$ S. Hosius, Opera omnia..., s. 63.

${ }^{46}$ Ibidem, s. 68.

${ }^{47}$ Ibidem, s. 79.
} 
Urbana Stömera - ten nie zgadzał się z jego opinią, że występowała różnica w sprawach doktrynalnych w ich głównych ośrodkach: „(...) nam certum esse diversam fidem esse Argentinensium a fide Wittembergensium, Magdeburgum vero iam utraque dissidere. Ille vero tres has Civitates in omnibus convenire affirmavit"48. Następnie Stanisław Hozjusz przeszedł do przedstawiania argumentów na rzecz swojego stanowiska (choćby sprawa związana z wyrzuceniem obrazów z kościołów przez Lutra, czego nie czyniono w Strassburgu). Ujął to w zgrabnej formie pytania retorycznego: „Nonne imagines Argentinae sunt eiectae quas eiici Martinus tuus Wittembergae passus non est?"49. Sam przyznał, że Stömer: „Negare non potuit”. Stanisław Hozjusz posłużył się biblijnym motywem wieży Babel, o którym wspomniał w następujących słowach: „Ita confudit Deus linguas eorum, qui turrim hanc Babel aedificare sunt conati et ipsas contra se mutua armavit" ${ }^{50}$. Według niego przywódcy reformacji, podobnie jak kiedyś budowniczowie wieży Babel, zostali ukarani przez Boga niezgodą, która wyrażała się w pomieszaniu ich języków („confudit Deus linguas eorum”).

Tego rodzaju postawa reformatorów wyrażała również według Hozjusza sprzeciw wobec wiary swoich przodków:

Recensui postea quae cum Ludimagistro egissem: hortatus illos sum, ne parentes, neve avos proavos et atavos suos idolatriae condemnarent, neve crederent, triginta iis annis Evangelium primum coepisse, quod praedicatum fuerit multo purius ante novos istos Evangelicos. Neque enim Ecclesiae suae Christum unquam defuisse, qui se cum illa promiserit, usque ad consumationem saeculi futurum ${ }^{51}$ : Nam si quis putaret lapsum esse in idolatriam universum Christianum Orbem, iam inde a tot seculis quid aliud quam ut mendacem Christum faceret et passionis et mortis illius merito detraheret ${ }^{52}$.

Ten fragment formułuje liczne zarzuty, które biskup chełmiński zręcznie ze sobą połączył, dokonując sprowadzenia ich założeń ad absurdum. Wynikało z nich bowiem, że dopiero od 30 lat byli w posiadaniu Ewangelii („triginta iis annis Evangelium primum coepisse”), a wcześniej cały świat

\footnotetext{
${ }^{48}$ Ibidem, s. 63.

${ }^{49}$ Ibidem.

${ }^{50}$ Ibidem.

${ }^{51}$ Nawiązanie do ostatniego ustępu Ewangelii wg św. Mateusza: „(...)docentes eos servare omnia, quaecumque mandavi vobis. Et ecce ego vobiscum sum omnibus diebus usque ad consummationem saeculi”. „Uczcie je zachowywać wszystko, co wam przykazałem. A oto Ja jestem z wami przez wszystkie dni, aż do skończenia świata". Cf. Matth 28,20.

${ }^{52}$ S. Hosius, Opera omnia, s. 65.
} 
chrześcijański oraz ich przodkowie byli pogrążeni w grzechu idolatrii. Piętnował w ten sposób nowinkarstwo, na które zwracał uwagę u zwolenników luterańskiego teologa Andrzeja Osiandra (1498-1552) w „Postępowaniu z elblążanami” $(1553)^{53}$. Według Hozjusza w ten sposób sugerowano, że Jezus Chrystus był kłamcą (mendacem), ponieważ wbrew zapewnieniom w ostatnim rozdziale Ewangelii wg św. Mateusza ${ }^{54}$ opuścił swój Nowo Wybrany Lud na wiele setek lat.

Właśnie słowo „Chrystus” pojawiało się w tym liście biskupa chełmińskiego do Marcina Kromera najczęściej - ponad 50 razy. Jako dobry retor właśnie to słowo obrał za rdzeń swojego wywodu ${ }^{55}$. Wiązało się to $\mathrm{z}$ poglądami polemisty Stanisława Hozjusza, Urbana Stömera, który jako luteranin był blisko związany z poglądami chrystocentrycznymi. Z tego względu katolicki polemista starał się wskazać niezgodności między nauką głoszoną przez reformowanych a prawdami głoszonymi przez Chrystusa. Ostatecznie w swoim liście do Kromera mógł stwierdzić, że ten heretyk nie miał żadnych argumentów na odparcie przedstawionych argumentów. Jednak pomimo tego nie zmienił swojego zdania ze względu na zatwardziałość serca. W relacji biskupa zostało to ujęte następująco: „Obsecro, inquit, liceat mihi per te meum institutum tenere: neminem in meam sententiam perducere conabor, ipse modo ut in ea perseverem" ${ }^{56}$. Zdołał jedynie uzyskać od heretyka zapewnienie, że nie będzie już nikogo nauczać i swoje poglądy zachowa dla siebie.

List Stanisława Hozjusza do Marcina Kromera z 15 kwietnia 1551 r. daje dość typowy wizerunek dostojnika kościelnego, który wykazuje się spokojem $\mathrm{w}$ przedstawianiu swoich racji ${ }^{57}$ oraz nie ulega gniewowi, pomimo braku skruchy i pozostaniu przy naukach luterańskich Urbana Stömera, mimo obalenia jego argumentacji (zastosowane środki to duża doza ironii, motywy biblijne, nawiązania do historii wczesnego chrześcijaństwa, wskazywanie na antyczność pewnych poglądów czy sprowadzanie pewnych założeń ad absurdum), oraz odzwierciedla charakter piszącego (ethos) ${ }^{58}$. Oczywiście należy

${ }^{53}$ Ibidem, s. 71.

${ }^{54}$ Cf. przyp. 44.

${ }^{55}$ Pamiętał o cenionym przez Cycerona aptum. Cf. Przyp. 16.

${ }^{56}$ S. Hosius, Opera omnia, s. 69.

${ }^{57}$ Hozjusz doskonale pamiętał o głównej zasadzie Cycerona, by mowa była stosowana celowo: „Oratoriam facultatem in eo genere ponemus, ut eam civilis scientiae partem esse dicamus" (Cic. De inv. I 5,6).

${ }^{58}$ Jedna z cech listu znamionujących jego poprawność. Było to ważne dla humanistów, odwołujących się do antycznych wzorców; cf. Antologia listu antycznego, oprac. J. Schnayder, Wrocław 1959, s. LXIV-LXV. 
mieć na względzie, że list pisany jest z perspektywy samego Stanisława Hozjusza i zapewne pełniejszy obraz dyskusji dałaby relacja innowiercy, z którym polemizował. Wizerunek ten jest odmienny od tego, jaki możemy odnaleźć w listach wysłanych przez Wielkiego Penitencjarza po tumulcie krakowskim (10 października 1574 r.) do biskupa krakowskiego Franciszka Krasińskiego $(1525-1577)^{59}$ oraz we wcześniejszym liście do kardynała Charlesa de Lorraine (1524-1574) po Nocy św. Bartłomieja (23-24 sierpień 1572$)^{60}$, kiedy miał wyrazić wielkie ukontentowanie z powodu pogromu niewiernych.

\section{Przemysław Stasiewicz \\ THE RHETORICAL ASPECT OF RELIGIOUS POLEMIC IN THE LIGHT OF THE LETTER OF STANISŁAW HOZJUSZ TO MARCIN KROMER DATED 15 OF APRIL, 1551}

\section{Summary}

The article is concerned the rhetoric which Stanisław Hozjusz employed in a polemic with a Torun Protestant, Urban Stömer, and the image of persons who engaged in the dispute. The latter was described in a letter of April 15th, 1551, that the Catholic clergyman wrote to Marcin Kromer. Both figures were sharply contrasted with one another, which served to show Stanisław Hozjusz, Bishop of Chełmno and a nominee for the Bishopric of Warmia as a benevolent and learned minister who refrained from using force and made every effort to convert those who strayed from faith. This was how he proceeded with Urban Stömer, whom he sought to convince using abundant arguments, drawing on biblical motifs, examples from early Chris-

59 „Czego nie śmiał ani król, ani biskupi to zrobić się ośmielili studenci akademii krakowskiej, godni wiekuistej pamięci, których chwałę cały Kościół sławić będzie. Karać ich za to, byłoby ściągać na cały kraj pomstę Bożą, raczej nagrodzić należy i starać się z całych sił, aby na miejsce zniszczonego Brogu żadna nie powstała synagoga szatana”. Cf. W. Sobieski, Nienawiść wyznaniowa tłumów za rządów Zygmunta III, Warszawa 1902, s. 32.

${ }^{60}$ Cf. A. Koraszewski, Cichy proces zmierzający do beatyfikacji łajdaka [online]. Racjonalista [dostęp: 2015-12-]. Dostępny w Internecie: <http://www.racjonalista.pl/kk.php/s,2185>, s. 1. Ten list budzi moje wielkie wątpliwości, ponieważ w zebranym przeze mnie materiale archiwalnym nie zetknąłem się z żadnym listem napisanym przez Stanisława Hozjusza między sierpniem 1572 a lipcem 1573 r., który byłby adresowany do Charlesa de Lorraine (1524-1574) lub jakiegokolwiek innego duchownego francuskiego. Dopiero 2 sierpnia 1573 r. wysłał on list do kardynała Senonensi, Nicolasa de Pellevé (1518-1594), w którym informował go o sytuacji w Polsce. Cf. oryg.: Paris Bibliotheque Nationale Mss. Francais nr 15967 k. 138r-140v., adres: Illustrissimo et Reverendissimo Domino meo observandissimo Domino Cardinali Senonensi. Moim zdaniem, jeśli takowy list rzeczywiście zostałby spisany przez Stanisława Hozjusza, byłby adresowany najprawdopodobniej nie do Charlesa de Lorraine, ale właśnie do znanego z bardzo nieprzejednanego stanowiska wobec innowierców Nicolasa de Pellevé'a. 
tianity and more contemporary times, citing authorities, using rhetorical questions, reducing certain views of the heretics ad absurdum, or embellishing much of his enunciations with characteristic irony. Ultimately, all arguments presented by Urban Stömer were refuted, but the heretic stood by his views. Thus, in the letter to Kromer, Hozjusz demonstrated how deeply the heretic was attached to erroneous conceptions and in a way exposed his irrational approach, which in Hozjusz's view was certainly a trait of many other sectaries. 


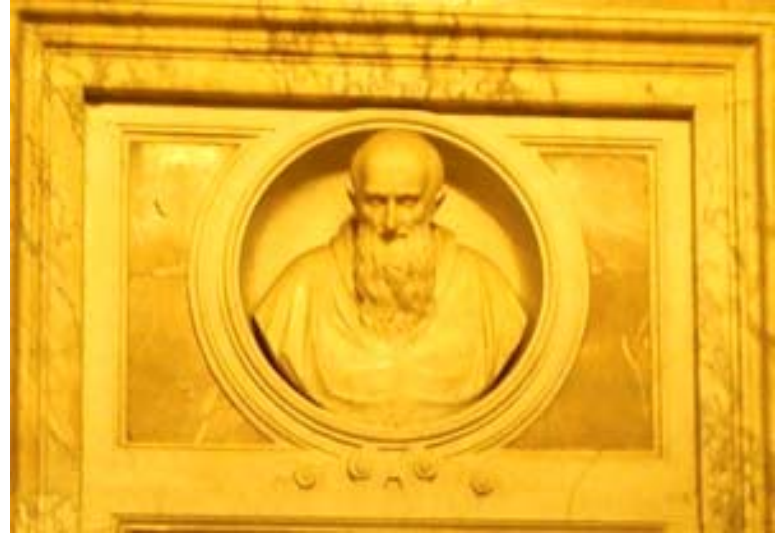

Ryc. 1. Wizerunek Stanisława Hozjusza (1504-1579) $\mathrm{z}$ monumentu nagrobnego $\mathrm{w}$ Basilica di Santa Maria in Trastevere (fot. Przemysław Stasiewicz).

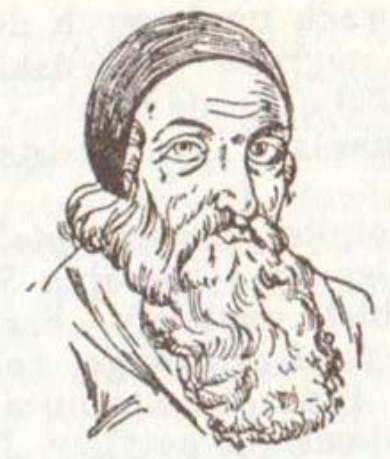

M. Kromer.

Ryc. 2. Ilustracja Marcina Kromera z: Wielka Ilustrowana Encyklopedia Powszechna Wydawnictwa Gutenberga, 8, Kraków 1994, s. 172.

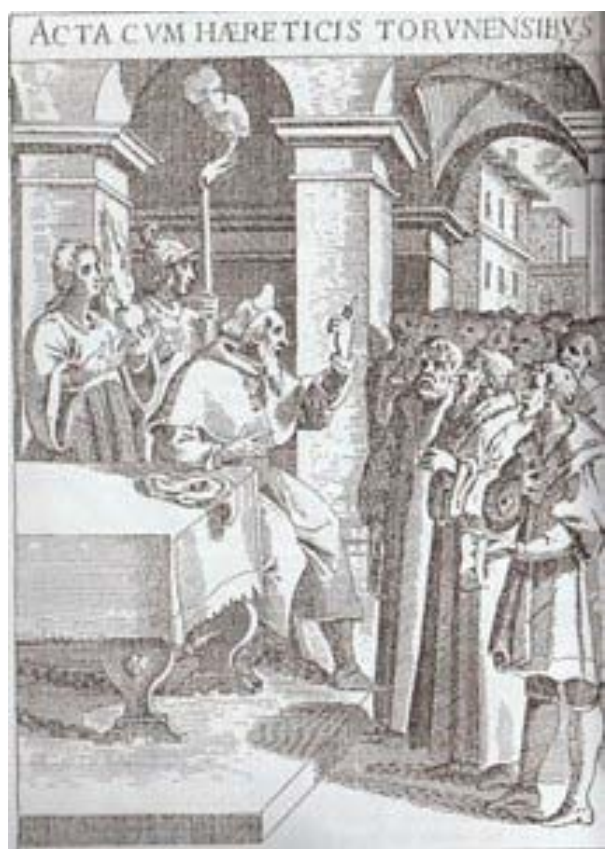

Ryc. 3. Postępowanie $\mathrm{z}$ heretykami toruńskimi. Rycina z dzieła Tomasza Tretera, Rewia cnót Stanisława Hozjusza, przeł. W. Steffen, Poznań 2004, s. 98.

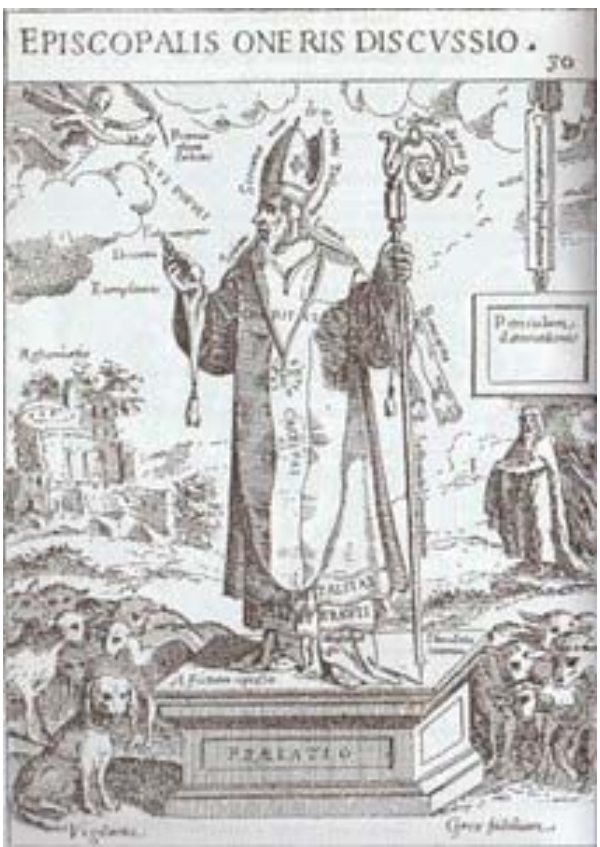

Ryc. 4. Rozważanie obowiązków biskupa. Rycina z dzieła Tomasza Tretera, Rewia cnót Stanisława Hozjusza, przeł. W. Steffen, Poznań 2004, s. 84. 


\section{Wykaz skrótów}

BJ - Biblioteka Jagiellońska

HE - Stanislaii Hosii, Epistulae et quae ad eum scriptae sunt (...), red. F. Hipler et V. Zakrzewski, 1, Kraków 1879

HV - Stanislaus Rescius, Vita Stanislai Hosii Poloni, (...) SRE Cardinalis, Maioris Poenitentiarii et Episcopi Varmiensis, Olivae 1690

NDB - Neue Deutsche Biographie

PDE - Pastoralblatt für die Diözese Ermland

PG - Patrologiae cursus completus. Patrologia Graeca, I-CLXI, oprac. J.P. Migne, Parisiis 1857-1866

PSB - Polski Słownik Biograficzny

\section{Bibliografia}

\section{Archiwalia i źródła drukowane}

Cicero M.T., De inventione; De optimo genere oratorum; Topica, Cambridge 1960.

Confessio fidei catholicae Christiana, avthoritate Synodi prouincialis quae habita est Petrcouiae, anno M. D. LI. Mense Iunio, edita: Praesid[en]te Peuerendissimo in Christo patre Domino dno Nicolao, Dei gratia Archiepiscopo Gnesnensi legato, nato et regni primate, Cracoviae 1553.

Hosius S., Confutatio prolegomenon Brentii, quae primum scripsit adversus venerabilem virum Petrum à Soto [...], Antwerp, 1561.

Hosius S., De Expresso Dei verbo: Ad Serenissimvm Dominvm, Dominvm Sigismvndvm Avgvstvm, Dei Gratia Regem Poloniae ... Libellvs Valde Vtilis [...], Dilinga 1558.

Hosius S., Opera omnia in duos divisa tomos (...), 1-2, Coloniae 1584.

Hozjusz S., O postępowaniu z odłączonymi, przeł. J. Wojtkowski, Olsztyn 2009.

M. Fabii Quintiliani Institutionis oratoriae libri duodecim, 1, oprac. M. Winterbottom, Oxford 2005.

M. Fabii Quintiliani Institutionis oratoriae libri duodecim, 2, oprac. M. Winterbottom, Oxford 1970.

M. Tullii Ciceronis de oratore libri tres, recogn. R. Klotz, Lipsiae 1873.

List Hozjusza do kard. Senonensi z 2 sierpnia 1573, oryg.: Paris Bibliotheque Nationale Mss. Francais nr 15967 k. 138r-140v. Adres: Illustrissimo et Reverendissimo Domino meo observandissimo Domino Cardinali Senonensi.

List Hozjusza do Kromera z 16 września 1561 roku Autograf BJ, rkps 60 s. 1025, pieczęć i adnotacja Kromera 26 Septembris Pragae.

Nova Vulgata Bibliorum Sacrorum Editio: Sacrosancti Oecumenici Concilii Vaticani II ratione habita, iussu Pauli PP. VI recognita, auctoritate Ioannis Pauli PP. II promulgata, Vatican 1986.

Patrologiae cursus completus. Patrologia Graeca, I-CLXI, oprac. J.P. Migne, Parisiis 1857-1866.

Pismo Święte Starego i Nowego Testamentu w przekładzie z języków oryginalnych (BT), opracował zespół biblistów polskich, Poznań 2003.

Stanislai Hosii Cracoviani in Lutheri sectatores epigramma, [w:] Erasmus Roterodamus, Hyperaspistes diatribae adversus Servuum Arbitrium Martini Lutheri, Cracoviae 1526.

Stanislai Hosii S.R.E. Cardinalis Maioris Poenitentiarii Episcopi Varmiensis (1504-1579) et quae ad eum scriptae sunt Epistolae tum etiam eius Orationes legationes (1525-1550) praemittuntur vita Hosii auctore Stanislao Rescio et Hosii opera iuvenilia, accedunt autem epistolae et acta, quae vitam et res gestas Hosii illustrant, editionem curaverunt F. Hipler, V. Zakrzewski, T. 1, Cracoviae 1879.

Treter T., Rewia cnót Stanisława Hozjusza, przeł. W. Steffen, Poznań 2004. 


\section{Opracowania}

Antologia listu antycznego, oprac. J. Schnayder, Wrocław-Kraków 1958.

Barycz H., Kromer Marcin, PSB 1970, 15, s. 319-324.

Hipler F., Johannes Chrisostomus und Stanislaus Hosius, PDE 2, 1878, s. 21-23.

Koraszewski A., Cichy proces zmierzający do beatyfikacji łajdaka [online]. Racjonalista [dostęp: 2011-09-02]. Dostępny w Internecie: <http://www.racjonalista.pl/kk.php/s,2185>.

Korolko M., Przewodnik encyklopedyczny, Warszawa 1990,

Kwintylian M.F., Kształcenie mówcy: księgi I, II i X, przeł. M. Brożek, Wrocław 1951.

Lausberg H., Retoryka literacka. Podstawy wiedzy o literaturze, przeł. i oprac. A. Gorzkowski, Bydgoszcz 2002.

Le Goff J., Historia i pamięć, przeł. A. Gronowska, J. Stryjczyk, Warszawa 2007.

Lichański J.Z., Retoryka od średniowiecza do baroku, Warszawa 1992.

Sobieski W., Nienawiść wyznaniowa tłumów za rządów Zygmunta III, Warszawa 1902.

Szczuczko W., Łacina szlachty Prus Królewskich w XVI i XVII wieku, [w:] J. Axer (red.), Łacina jako język elit, Warszawa 2004, s. 121-131.

Urban W., Stanisław Hozjusz, PSB 1962-1964, 10, s. 42-46.

Werl E., Georg der Bärtige (oder der Reiche), Neue Deutsche Biographie 6, Berlin 1964, s. 224-227.

Wielka Ilustrowana Encyklopedia Powszechna Wydawnictwa Gutenberga, 16, Kraków 1995.

Wojtkowski J., Czynności religijne Stanisława Hozjusza w diecezjach: chełmińskiej i warmińskiej, [w:] S. Achremczyk, J. Guzowski, J. Jezierski (red.), Kardynał Stanisław Hozjusz (1504-1579). Osoba, myśl, dzieło, czasy, znaczenie, Olsztyn 2005, s. 77-97. 